\title{
Musically Consonant, Socially Dissonant: Orange Walks and Catholic Interpretation in West-Central Scotland
}

\author{
STEPHEN R. MILLAR
}

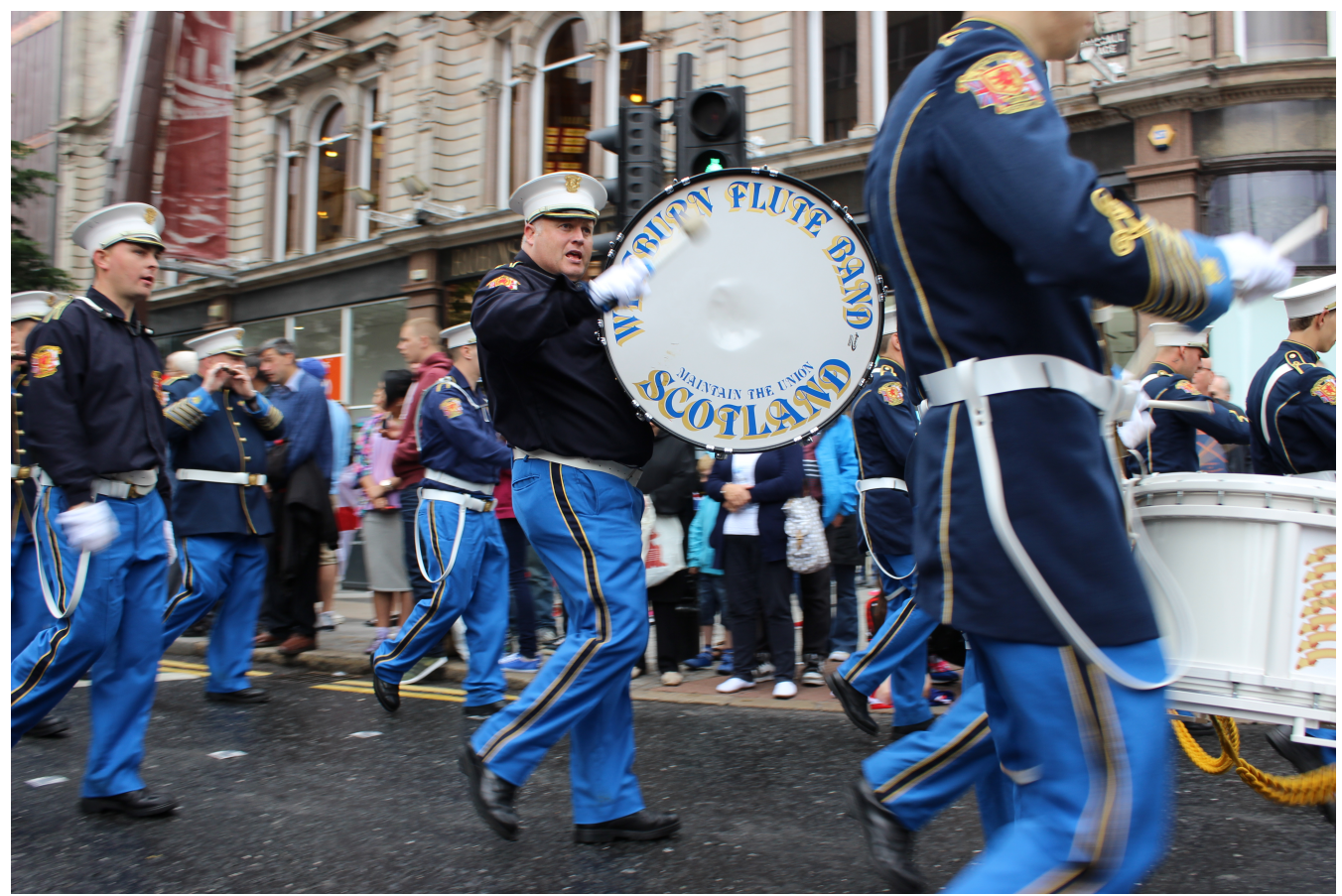

Image 1: Whitburn Flute Band. Photograph by author.

\section{"Scotland's Shame"}

In August 1999, Scotland's pre-eminent composer launched a stinging attack on the country's deeply ingrained religious bigotry. ${ }^{1}$ During a lecture entitled "Scotland's Shame," part of the Edinburgh Festival, James MacMillan called sectarianism "a defining feature of Scotland." ${ }^{2}$ The lecture sparked a national debate, and Scotland's largest broadsheet, The Herald, printed three editorials, seventeen articles, and almost one hundred letters on the topic in the two weeks that followed MacMillan's speech. Fifteen years have passed since MacMillan delivered his polemic against Scotland's "visceral anti-Catholicism," with many groups and initiatives trying to tackle the problem. ${ }^{3}$ In 2003, the Scottish Government introduced

\footnotetext{
${ }^{1}$ This article is based on a paper presented at a peer-reviewed collaborative workshop between the Arts and Humanities Research Council and the British Broadcasting Corporation at the BBC's headquarters in London. The AHRC called for researchers to help inform and influence BBC programming for 2014, which would coincide with the XX Commonwealth Games in Glasgow and a referendum on Scottish independence. The workshop was held on April 26, 2013. The author would like to thank Simon McKerrell, Katy Radford and the paper's two anonymous readers for their comments, support, and encouragement.

${ }^{2}$ James MacMillan, "Scotland's Shame?" in Scotland's Shame? Bigotry and Sectarianism in Modern Scotland, ed. T. M. Devine (Edinburgh: Mainstream, 2000), 24.

${ }^{3}$ These groups include: Nil By Mouth, Sense Over Sectarianism, Show Racism The Red Card and two Scottish Governments,
} 
the Section 74 of the Criminal Justice (Scotland) Act, which made "religious aggravation" a statutory offence and required that the justice system record the incidence of violent crimes with "sectarian overtones." " In 2011 the ruling SNP Government pledged £9 million to tackle sectarianism over three years and-more controversially_introduced the "Offensive Behaviour at Football and Threatening Communications (Scotland) Bill," following a series of events that included Rangers Football Club being fined over its fans singing "sectarian songs," an attempt to bomb three prominent supporters of Celtic Football Club, and a live bullet being posted through the mailbox of Cardinal Keith O'Brien. ${ }^{5}$ Enacted on March 1, 2012, the new law made the singing of "sectarian songs" punishable by an unlimited fine and up to five years in prison. Yet it included no definition of what constituted a sectarian song. ${ }^{6}$ While many different groups have sought to address "Scotland's Shame," few have attempted to chart the role music plays in perpetuating religious bigotry in Scotland. ${ }^{7}$ This article attempts to redress the apparent gap in the literature by examining the history of one of the most well-known sectarian songs, namely "The Sash My Father Wore." It charts the history of "The Sash," its contentious use in west-central Scotland, and the extramusical factors that have led to its being used as a weapon against Scotland's minority Catholic population.

In the context of modern Scotland, most people understand "sectarianism" as conflict between Catholics, predominantly of Irish descent, and Protestants. ${ }^{8}$ However, it is largely confined to the central belt of the country, and its effects are most keenly felt in the west, in such areas as Glasgow, Lanarkshire, and Ayrshire, where the majority of Scotland's Catholics reside. ${ }^{9}$ Sectarianism in Scotland dates back to the Reformation, which saw the country adopt a stricter and more puritanical Protestantism than its southerly neighbor. Indeed, while the Anglican Church maintained much of the ceremony and symbolism of the Catholic Church, considering itself both Catholic and Reformed, in Scotland the two were mutually exclusive.

Sectarianism in Scotland assumed a new dimension with the mass Irish immigration of the midnineteenth century, when millions fled the devastating effects of Ireland's famine of 1845-1849. Proportionately, Scotland already had a larger Irish community than either England or Wales, ${ }^{10}$ and many of these new immigrants chose to settle there due to its cultural and geographical closeness. Irish immigrants were drawn to the west of Scotland by the presence of heavy industry, yet substantial pockets

the Labour-Liberal coalition of 1999-2007 and the Scottish National Party (SNP) Government of 2007-present. Nil By Mouth has conducted highly visible campaigns to combat sectarianism, making extensive use of advertising and educational programs to highlight the problem. One poster features the line "Sing sectarian songs and you could end up in the theatre" and is accompanied by a photograph of someone undergoing surgery in a medical theater. See Stephen Simpson and Richard Rogers, the website of Do Good Advertising, accessed 22 July 2014, http://www.dogoodadvertising.com/old-do-goodadvertisig-site-2006/portfolio old work.html.

${ }^{4}$ Michael Rosie, The Sectarian Myth in Scotland: Of Bitter Memory and Bigotry (Basingstoke: Palgrave Macmillan, 2004$), 4$.

${ }^{5}$ David Leask and Gerry Braiden, "Bomber is Scotland's Most Dangerous Man," The Herald, 21 April 2011.

${ }^{6}$ See the Scottish Government's website: http://www.scotland.gov.uk/Topics/Justice/law/sectarianism-action-1/footballviolence/bill

${ }^{7}$ One notable exception is Simon McKerrell's "Hearing Sectarianism: Understanding Scottish Sectarianism as Song," Critical Discourse Studies (2012): 1-12.

${ }^{8}$ It is important to state that in this article, the terms "Catholic" and "Protestant" refer not only to those who practice their faith. In Scotland, as in Northern Ireland, the terms "Catholic" and "Protestant" imply membership in the Catholic and Protestant communities, encompassing social, political, cultural, and religious factors to form a distinct, sub-national identity. This nomenclature will continue throughout the paper. For an extended definition of Catholic and Protestant identity see Ian Adamson, “The Ulster Scottish Connection,” in Scotland \& Ulster (Edinburgh: Mercat Press, 1994), 1-21.

${ }^{9}$ Steve Bruce et al., Sectarianism in Scotland (Edinburgh: Edinburgh University Press, 2004), 10.

${ }^{10}$ Eric J. Evans, The Forging of the Modern State: Early Industrial Britain, 1783-1870, 3rd ed. (Harlow, England: Longman, 2001), 383, 455 . 


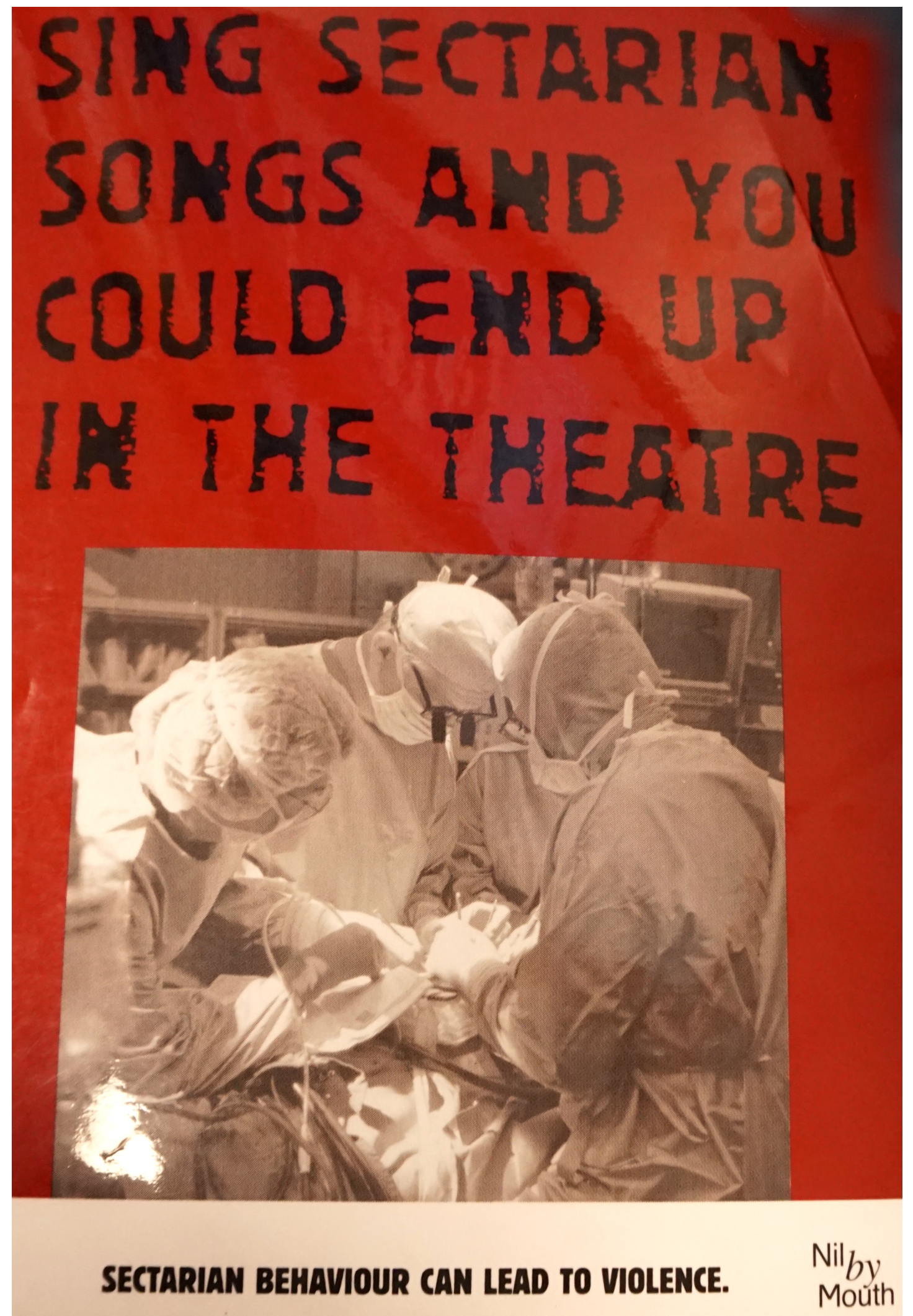

Image 2: Nil By Mouth campaign poster. Used with permission. 
of Irish also settled in Edinburgh and Dundee. ${ }^{11}$ Three quarters of Irish immigrants were Catholic, in contrast to Scotland's Presbyterian Protestant majority; thus, their alterity was doubled, being a national and religious minority. The remaining quarter were Ulster Protestants, who forged cultural and political ties with the country's loyalist population and did not suffer the same discrimination as their Catholic countrymen. ${ }^{12}$ Ireland's sectarian tensions and attitudes accompanied both immigrant groups, mapping themselves onto the prejudice already existent within Scottish society, creating two prevailing identities in west-central Scotland: Irish Catholic and British Protestant. While modern-day sectarianism is most visible through the rivalry of the country's two biggest football teams, Glasgow's "Catholic" Celtic and "Protestant" Rangers, ${ }^{13}$ it is not confined to sport. In Scotland, sectarianism is difficult to define on account of its being fused with social, economic, political, and religious factors. ${ }^{14}$ Yet its effects are keenly felt.

In 2003, Glasgow City Council commissioned a report on sectarianism in Glasgow where a representative sample of 1,000 adults were asked a series of questions on the extent and nature of prejudice in Glasgow, personal experiences of prejudice and discrimination, attitudes towards different social groups, experience of crime, and the links between crime and sectarianism and other forms of prejudice. The study utilized telephone interviews; consultations with religious, sporting, charitable, and governmental organizations; and qualitative data from thirteen focus groups divided by religion, age, sex, social class, and ethnicity. It found that 65 percent of residents believed sectarian violence was "very or quite common," while 58 percent believed sectarian threats and harassment were common. The vast majority saw sectarianism as a current and ongoing problem in Glasgow, "with two-thirds of respondents disagreeing with the statement that sectarianism is becoming a thing of the past." 15

\section{Orange Walks and Catholic Interpretation}

*Walking the Orange Walk is sectarian behaviour.

$\star A y e$ and they can say it's historically significant but it isn't historical, it is anti-Catholic.

^It's lost in history now. It's totally hatred-motivated and no way does it go back to history because I don't think half of them have enough brains to know what the history is about.

*The younger ones don't but I think it is just an excuse for violence. ${ }^{16}$

\footnotetext{
${ }^{11}$ Graham Davis, The Irish in Britain 1815-1914. (Dublin: Gill and Macmillan, 1991), 68.

${ }^{12}$ Andrew Davies, “They Sing That Song': Football and Sectarianism in Glasgow during the 1920s and 1930s,” in Bigotry, Football and Scotland, edited by John Flint and John Kelly (Edinburgh: Edinburgh University Press, 2013 ), 52.

${ }^{13}$ Celtic Football Club was founded by an Irish Catholic monk, Brother Walfrid, who sought to provide an outlet for Glasgow's poor Irish immigrant population. Formed in 1887 amidst the Home Rule movement for Ireland, Celtic invoked Irish nationalist politics from its inception and served as the "standard-bearer" of the city's Irish-Catholic community. During the 1890s, Rangers was increasingly identified as Glasgow's Protestant team, and games between the two "quickly acquired the backdrop of religious bigotry which has characterised encounters between the teams ever since.” Ibid., 50.

${ }^{14}$ Peter Kearney, director of the Scottish Catholic media office, expressed the widespread misunderstanding of the term "sectarianism" in a letter regarding the singing of sectarian songs and chants at football matches. He wrote: "If neither the [football] fans who sing sectarian songs nor the officials charged with policing them have an accurate understanding or definition of the term, it seems unlikely that they will be able to respond, far less eradicate such behaviour. . . Rather than convening further high-profile summits or eye-catching headlines, what is needed most of all is an informed definition of the term 'sectarianism' and a renewed pledge from everyone involved in football not to tolerate it." "We need an informed definition of sectarianism and commitment to fight it," The Herald, 31 March 2011, 15.

${ }^{15}$ NFO Social Research, "Sectarianism in Glasgow - Final Report” (Edinburgh: NFO Social Research, 2003), 7-15.

${ }^{16}$ Protestant Focus Group, "Sectarianism in Glasgow - Final Report," 46.
} 
An Orange Walk is a public parade organized by the Orange Order, an exclusively Protestant fraternal organization, celebrating the victory of the Dutch Protestant Prince William of Orange over the English Catholic King James, on 12 July 1690, at the Battle of the Boyne. ${ }^{17}$ William's victory guaranteed British sovereignty and greatly reduced papal influence on affairs of the state. James escaped to France, and William was offered the British throne, conditional upon his introducing a Bill of Rights, which included parliamentary protections for free speech and free elections: "For Protestants this was the Glorious Revolution. For Catholics there was nothing to celebrate: parliament was less tolerant than the new king, and the Toleration Act of 1689 excluded Catholics, Jews, and Unitarians from the right to worship freely." 18 Thus, while some Protestants celebrate King William's victory as bringing religious freedom to Scotland, for many Catholics it marked the beginning of a religious and cultural oppression, which, some argue, persists to this day. ${ }^{19}$

In Material Conflicts, Neil Jarman describes the full spectacle of an Orange Walk:

The aggressive 'blood and thunder' flute bands dominate the Belfast parade,$^{20}$ and concentrate on marching and party tunes with a strong percussive beat, ${ }^{21}$ which they play from memory. Most bands are independent of the Orange Order and hired just for the day. Many are critical of the loyal orders and are closer to the loyalist paramilitary groups; but by participating in the Orange parades the bands affirm their support for the general unionist position, although without necessarily conforming to the Orange ideals.

... While it may be possible to banish the more extreme regalia from the parade, it is more difficult to control the many sectarian anthems that are beaten out with gusto and regularity that delights the crowds. A parade without bands has little appeal for spectators, and the rhythm of the drums helps pass the miles to the Field; this is why most lodges continue to hire a band, even if they disapprove of some aspects of their displays. The parade is awash with noise over the entire route ... Each band plays at its own preferred volume, regardless of neighbouring bands, so that at any one time spectators are likely to be able to hear three different tunes, one from the band that has just passed, one from the one in front of them and one from the one approaching. Most spectators stay at one spot to watch the parade pass; but many of the blood and thunder bands are accompanied by a crowd of friends and girlfriends, who walk along the pavement, cheering and encouraging the bandsmen and joining in with some of the tunes. Friends also help with the important business of supplying refreshments;

\footnotetext{
${ }^{17}$ James was ruler of three Kingdoms, being titled King James II of England and Ireland, and King James VII of Scotland.

${ }^{18}$ Ruth Dudley Edwards, The Faithful Tribe: An Intimate Portrait of the Loyal Institutions (London: HarperCollins, 1999$)$, 150.

${ }^{19}$ Although the gap between Scotland's Catholic and Protestant population is narrowing, figures from the 2001 census show Catholics are still more likely to work in lower-status jobs than their Protestant counterparts. See T.M. Devine, "The End of Disadvantage?" in New Perspectives on the Irish in Scotland, ed. Martin J. Mitchell (Edinburgh: John Donald, 2008$), 202$.

Catholics are also more likely to be victims of sectarian abuse than Protestants and, despite comprising some 16 percent of Scotland's population, account for 56.5 percent of those abused on the grounds of their religion. See Liz Levy "An Examination of the Evidence on Sectarianism in Scotland," (Scottish Government Social Research: Justice Analytical Services, 2013), 4. Catholics comprise Scotland and the United Kingdom's largest minority group. In the UK, the Catholic community is fifteen times bigger than the Jewish community, yet while the first Jewish Prime Minister was elected in 1874, the position has never been held by a Catholic. Dennis Sewell, Catholics: Britain's Largest Minority (London: Viking, 2001$), 2$. That the British Monarch is expressly forbidden from being Catholic, swearing an oath to maintain "the laws of God, the true profession of the Gospel and the Protestant Reformed Religion established by law," further adds to the perception that Catholics are subject to religious discrimination in Scotland and the UK. See George Scott, The R.Cs: A Report on Roman Catholics in Britain Today (London: Hutchinson, 1967), 71.

${ }^{20}$ Blood and Thunder bands gained their name because the drummers who beat the lambeg drums were encouraged to strike them so hard that their hands often bled, staining the drum. See Jacqueline Witherow, “The 'War on Terrorism' and Protestant Parading Bands in Northern Ireland,” Quest (Queen's University Belfast), no. 1 (2006), http://www.qub.ac.uk/sites/QUEST/.

${ }^{21}$ For more detailed discussion on loyalists and their music see Katy Radford, "Red, White, Blue and Orange: An Exploration of Historically Bound Allegiances through Loyalist Song," The World of Music, 46, no. 1 (2004): 71-89.
} 
soft drinks are usually consumed on the route, but beers are expected at the Field. Accompanying supporters are usually seen with carrier bags full of cans of lager. ${ }^{22}$

Although Jarman's description pertains to a Northern Irish Orange Walk, the format in Scotland is generally the same, with "Blood and Thunder" bands also predominating the scene. Many of those who participate in Northern Irish Orange Walks also take part in Scottish parades and vice versa. Thus the cultural, historical, and ethno-religious bonds between the two peoples are upheld and renewed each year, maintaining strong links between the west of Scotland and the north of Ireland. ${ }^{23}$

Video 1: Orange Walk in Glasgow City Center

View at: http://dx.doi.org/10.3998/mp.9460447.0009.102

The 2005 Review of Marches and Parades, compiled by Sir John Orr, revealed that from 2001 to 2003 half of all public processions were categorized as "Orange": in these three years there were 2,485 Orange processions held in Scotland. ${ }^{24}$ While Catholics comprise roughly 16 percent of the population, forming Scotland's largest ethno-religious minority, a mere 1 percent of all notified public processions from 2001 to 2003 had a Catholic theme. ${ }^{25}$ Further, these processions tend to be much smaller affairs and do not command the same audiences as their Protestant counterparts. Through their size, frequency, and the large numbers of disreputable "hangers-on" they attract, Orange Walks are an interesting phenomenon. ${ }^{26}$ They are also on the increase. The Orr report concluded that of all categories of marches and parades in Scotland "The 'Orange' has seen the steadiest growth from 800 in 2001, 832 in 2002 and 853 in 2003."27 Glasgow now hosts more Orange Walks each year than Belfast and Derry/Londonderry combined. ${ }^{28}$

Despite the large numbers that turn out in support of Scotland's Orange Walks, whether it be for social or religious reasons, or merely to witness the spectacle, there are many who oppose them and believe that they should be banned on account of their fanning the flames of sectarianism. However, an important distinction must be made in that while the majority of respondents to the NFO's 2003 survey favored Orange Walks be banned outright, many considered the spectators—not the participants—to be the main source of sectarian conflict. ${ }^{29}$

\footnotetext{
${ }^{22}$ Neil Jarman, Material Conflicts: Parades and Visual Displays in Northern Ireland (Oxford: Berg, 1997), $102-103$.

${ }^{23}$ For an ethnographic account of the communal bonds and identities between loyalist bandsmen in Northern Ireland and the west of Scotland, see Ramsey's description of the Sir George White Memorial band's annual trip to New Cumnock, in which they experience a "short but emotionally intense period of musicking ... enacted and embodied in experiences of 'shared flow,' or ‘communitas.”' Gordon Ramsey, Music, Emotion and Identity in Ulster Marching Bands (Bern: Peter Lang, 2011), 155-184.

${ }^{24}$ John Orr, Review of Marches and Parades in Scotland (Edinburgh: Scottish Executive, St Andrews House, 2005), 64-65.

${ }^{25}$ The Orr report categorizes "Catholic" parades as those organized by the Ancient Order of Hibernians. Ibid., 25.

${ }^{26}$ Orange Walks and their spectators are often ridiculed in the press, with a columnist for Scotland's leading broadsheet referring to them as "inbred lumpen scum" and other reporters referring to Drumcree Orangemen as "white trash" in 1997. See Graham Walker, "Sectarian Tensions in Scotland: Social and Cultural Dynamics and the Politics of Perception" in Scotland's Shame?, 130.

${ }^{27}$ Prior to the publication of Sir John Orr's report, Professor T.G. Fraser of the University of Ulster found that "Orangeism in Scotland is on the increase, an integral part of our culture, its multiplying marches an established feature of west-central Scotland." See Patrick Reilly, "Kicking With the Left Foot: Being Catholic in Scotland" in Scotland's Shame?, 29.

${ }^{28}$ Gerry Braiden, "Glasgow has more parades than Belfast and Londonderry combined," The Herald, 21 August 2009, http://www.heraldscotland.com/news/home-news/glasgow-has-more-parades-than-belfast-and-londonderry-combined1.823788 .

29 "The survey asked respondents if they agreed that Orange Walks and Catholic/Irish Republican Parades should be banned in Glasgow. . . Overall, 53\% of respondents said that Orange Walks should be banned and 56\% said that Catholic Parades should be banned." See NFO, "Sectarianism in Glasgow," 44.
} 
^I am not against people having religious freedom but look at the Orange Walk it is highjacked for people's prejudices. The people who take part in the walk are fine - it is the followers. ${ }^{30}$

Elaine McFarland dates the Orange Order's first attempt at a full ceremonial Twelfth of July parade in Scotland to 1821. She writes:

Only three lodges took part on this first occasion, parading through the principal streets of Glasgow. Watched by 'an immense concourse of spectators' they were roughly handled and some had their sashes torn off. ... In 1822 the pattern was repeated. Now seven lodges including those from Paisley and Pollokshaws, assembled to march, contrary to the magistrate's proscription, to Fraser's Hall in King Street. The company met with little opposition during the march since it was unexpected. Once inside the hall, however, they were besieged by a number of 'zealous Irish catholics [sic], most ready to give battle'. Police and even military intervention was required and 127 Orangemen were taken into their safekeeping, returning home ignominiously 'with sashes in their pockets'. A parade was again threatened for the following year but was cancelled and no public Orange processions seem to have taken place in Glasgow till the 1840s. ${ }^{31}$

Interestingly, while 1821 marked the year of Scotland's first Orange Walk, it was also the year of its first media attack. The Orange Walk was criticized by both the Glasgow Courier and the Chronicle. A letter published in the latter read:

With the opinions of the Orangemen the public have nothing to do so long as they keep those opinions to themselves: but what right do the peaceful inhabitants of Glasgow have to be frightened out of their propriety by the wanders through the streets of a set of enthusiasts who ... are never against having recourse to the shillelah. ${ }^{32}$

Though the letter above was written almost two centuries ago, the sentiment would likely resonate with many Glasgow residents today, who bemoan the Orange Walks they are frequently forced to endure during the summer's marching season. In a similar comparison of past and present, the west-central and predominantly Catholic town of Coatbridge suffered "serious outbreaks" of sectarian violence from 1857 through to the 1990s; this regularly accompanied the town's annual Twelfth of July Orange Walks. ${ }^{33}$ Thus, the a priori that violent incidents increase as Orange Walks parade through highly populated Catholic communities seems to hold true, suggesting that Scottish Catholics perceive Orange Walks as offensive and directed at them.

\section{"The Sash My Father Wore"}

People have this great thing: "what's your favorite piece of music?" . . and it depends on who I'm talking to. . . . If I'm talking to people that wear my colors, I tell them sincerely that there is one and one only tune and on the morning of the twelfth it brings tears to my eyes. I remember friends that are not there, my heart leaps and I get a lump in my throat-it's The Sash. ${ }^{34}$

\footnotetext{
${ }^{30}$ Skilled and non-skilled female manual workers focus group aged 40-60. Ibid., 13.

${ }^{31}$ E. W. McFarland, Protestants First: Orangeism in Nineteenth Century Scotland (Edinburgh: Edinburgh University Press, 1990), 51.

${ }^{32}$ Ibid., 52.

${ }^{33}$ Joseph M. Bradley, Ethnic and Religious Identity in Modern Scotland: Culture, Politics and Football (Aldershot: Ashgate, 1995), 14.

${ }^{34}$ Private Communication, Orange Lodge Member, Glasgow, 2010.
} 


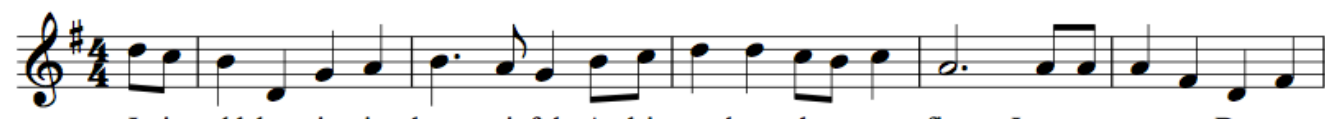

It is old, but it is beau-ti-ful, And its co-lours th-ey are fine, It was worn at Der-ry,

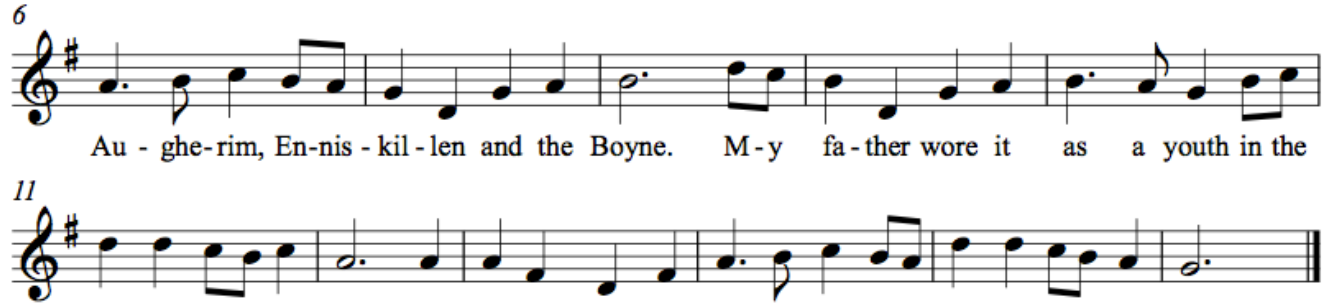

by-gone da-ys of yore, And on the Twelfth I love to wear th-e sash my f-a-ther wore.

Image 3: Chorus of "The Sash My Father Wore." Transcribed by the author.

\section{Verses and Chorus of "The Sash My Father Wore"}

Sure I'm an Ulster Orangeman, from Erin's Isle I came, To see my British Brethren all of honor and of fame, ${ }^{35}$

And to tell them of my forefathers who fought in days of yore, That I might have the right to wear The Sash my father wore!

Chorus: It is old but it is beautiful, and its colors they are fine, It was worn at Derry, Aughrim, Enniskillen and the Boyne.

My father wore it as a youth in bygone days of yore,

And on the Twelfth I love to wear The Sash my father wore.

For those brave men who crossed the Boyne have not fought or died in vain, Our Unity, Religion, Laws and Freedom to maintain,

If the call should come we'll follow the drum, and cross that river once more,

That tomorrow's Ulsterman may wear The Sash my father wore!

Chorus

And when some day, across the sea to Antrim's shore you come,

We'll welcome you in royal style, to the sound of flute and drum, And Ulster's hills shall echo still, from Rathlin to Dromore,

As we sing again the loyal strain of The Sash my father wore!

Chorus

While it may seem somewhat innocuous, "The Sash My Father Wore" splits opinion across Scottish society. To some, the song is a symbol of "national" pride and, in singing "The Sash," they feel connected to a tradition that stretches back generations within their family. It serves as a Protestant beacon, offering familiarity and reassurance, providing its listeners with a sense of regional and, through its evocation of British imperialism, international significance in an ever-changing, more globalized world. To others, this song constitutes something akin to torture, a reminder of the harsh inequalities that Catholics were subjected to and a warning that they are still seen as an Other in Scotland. The song paints a romanticized notion of the Dutch King William's victory over the English Catholic King James and revels in the victory

\footnotetext{
${ }^{35}$ In Glasgow one often hears the second line, "To see my British Brethren," substituted with "To see my Glasgow Brethren."
} 
of Protestantism over Catholicism. The song's saccharine treatment of the relationship between British and Irish Protestants and its yearning for a return to simpler times help elevate "The Sash" as the de facto anthem of Orangeism and the Orange Order. ${ }^{36}$

However, despite the popularity of "The Sash," the frequency with which it is sung, and its importance within the Orange Order, it is historically inaccurate: since the Orange Order did not come into existence until 1795, it goes without saying that its sash could not have been worn a century previous. The myth of "The Sash" is an example of what Eric Hobsbawm refers to as an "invented tradition": "a set of practices ... which seek to inculcate certain values and norms of behaviour by repetition, which automatically implies continuity with the past." ${ }^{37}$ While Hobsbawm's research on invented traditions primarily concerns the legitimacy these traditions afford the modern state, he spends some time relating his theory to the organization of groups and the role it plays in cementing group cohesion. Hobsbawm sets out three-overlapping - types of invented tradition that have developed since the Industrial Revolution:

a) those establishing or symbolizing social cohesion or the membership of groups, real or artificial communities, b) those establishing or legitimizing institutions, status or relations of authority, and c) those whose main purpose was socialization, the inculcation of beliefs, value systems and conventions of behaviour. ${ }^{38}$

The Orange Walks organized by the Orange Order conform to all three aspects of Hobsbawm's invented traditions: they establish social cohesion and group membership among a large minority of Scotland's Protestant population; through the sheer size of their displays, coupled with the public support they enjoy, Orange Walks re-establish the connection between Orangeism and Scottish society, legitimizing the status of the Order; and they offer the Order an opportunity to inculcate spectators to their religious cause and instill Protestant values on an increasingly secular Scottish society. ${ }^{39}$

As the Orange Order came into being in 1795, a century after the event it principally celebrates, ritualistic songs like "The Sash" are crucial in connecting past with present, serving to construct and reaffirm the Order's connections with history. The first recorded Orange Walk to take place in Scotland was not until 1821, and after the violence following the 1822 parade, there were no Orange Walks in Glasgow until the 1840s. ${ }^{40}$ Further violence prompted another ban and from 1857 to 1872 there were no Orange Walks in Glasgow or Lanarkshire. ${ }^{41}$ The Order's history is fraught with fracture, disunity, and dissolution, yet the incorporation of songs such as "The Sash," "Derry's Walls," and "Boyne Water" into the folklore of the organization helps to present the Orange Order as a cohesive group. ${ }^{42}$ The Orange Order has many traditions, both authentic and invented, from which to draw upon, yet its music helps

\footnotetext{
${ }^{36}$ The song was first published in the Glasgow songbook The Orange Standard in 1936 by Mozart Allen. For more detail see Susan Motherway, The Globalization of Irish Traditional Song Performance (Aldershot: Ashgate, 2013), 133.

${ }^{37}$ Eric Hobsbawm, "Inventing Traditions" in The Invention of Tradition, 20th ed., ed. Eric Hobsbawm and Terrence Ranger (Cambridge, England: Cambridge University Press, 2012), 1.

${ }^{38}$ Ibid., 9.

${ }^{39}$ Collocation of the Orange Order and Rangers Football Club, expressed through spectators' wearing Rangers football shirts, also serves to strengthen the Orange display. This is discussed in more detail later in the article.

${ }^{40} \mathrm{McF}$ arland, Protestants First, 51.

${ }^{41}$ Andrew Davies, City of Gangs: Glasgow and the Rise of the British Gangster (London: Hodder and Stoughton, 2013 ), 12.

${ }^{42}$ The Orange Order was dissolved by its Imperial Grand Master, the Duke of Cumberland, on 26 February 1836 in Britain and April 1836 in Ireland following the results of a House of Commons Select Committee which found that "Orangemen controlled the Irish Yeomanry; Orangemen enjoyed a certain measure of immunity from justice in the North of Ireland; Orangemen were frequently engaged in civil disturbances and riots; Orange Lodges existed illegally in the Army and the Order was a source of patronage for persons wishing to procure licenses for public houses. In addition, many Orangemen possessed firearms which was a threat to the rule of law." William S. Marshall, 'The Billy Boys Boys': A Concise History of Orangeism in Scotland (Edinburgh: Mercat Press, 1996), 25.
} 
bring these disparate rituals together to reinforce the aspect of continuity and strengthen the notion that it is a single cohesive force flowing directly from 1690.

Ironically, "The Sash" is a microcosm of the wider debate in that while it serves a practical function as a song to march to, the song itself is an invented tradition. The melody on which "The Sash" is based was taken from an Irish-American music hall song, "My Irish Molly-oh." ${ }^{43}$ While writing new words and applying them to a pre-existing tune is not uncommon within music, the technical term for which is contrafacta, it assumes a new dimension when one considers that the actual melody of "The Sash" is now interpreted by many Scottish Catholics as a form of codified sectarianism. First published in 1936, "The Sash" came to replace the more belligerent and overtly sectarian songs popular at the end of the nineteenth century such as "Dolly's Brae," "Slitter-Slatter," and "Up Comes a Man." ${ }^{* 4}$ Sam Hanna Bell explains that a "stranger reading the lyrics usually attached to these melodies by some 'Collector and Arranger' would think them colourless enough. . . But these chunks of poesy bear no resemblance whatever to the words evoked in most Ulstermen when they hear the tunes played." 45 Bell's point is as true among Scottish Orangemen as it is with those living in Ulster. ${ }^{46}$ Due to the wide use of contrafacta in sectarian music and the tendency for groups to substitute somewhat tame lyrics for offensive ones, merely looking at the "official" lyrics, compiled by "collectors and arrangers," does not provide an accurate account of the content or offensive nature of these songs. ${ }^{47}$ While the original version of "Dolly's Brae" features lines certain to offend Catholics_-such as "Be gone, be gone you Papish dogs, you've hardly time to pray, / Before we throw your carcasses right over Dolly's Brae"-modern interpretations are even more explicit. The Thornlie Boys, a Scottish loyalist band, have recorded a version of "Dolly's Brae" that substitutes the line "For the tune we played was the Protestant Boys right over Dolly's Brae" with the more offensive "For the tune we played was fuck the Pope right over Dolly's Brae."

"The Sash" does not feature any of the vitriolic, anti-Catholic lines quoted above and has few lines that could be considered overtly sectarian. Yet, ironically, the song employed to sanitize Orangeism and the Orange Walk has itself become mired in sectarian controversy. Whether this is because of the more overtly sectarian songs it replaced, and a reckoning that "The Sash" is of a similar ilk, or the militarism and bravado accompanying its performance, "The Sash" is perceived as a form of codified sectarianism. Either way, if the song is perceived as being sectarian, it becomes sectarian. A similar argument is often made of the relationship between Wagner and anti-Semitism. With reference to Daniel Barenboim's performance of Wagner in Israel, Richard Taruskin writes "[i]t does no good to argue that music itself is inherently nonpolitical and nonracist. The music does not now exist, nor has it ever existed, in a social vacuum. Its meanings are not self-contained." ${ }^{49}$

At its peak, the Orange Order had fifteen Orange Lodges in the east of Scotland, while in the west,

\footnotetext{
${ }^{43}$ See Katy Radford, "Drum Rolls and Gender Roles in Protestant Marching Bands in Belfast," British fournal of Ethnomusicology 10, no. 2 (2001): 37-59. For a detailed comparison of the two songs, see David Cooper, "On the Twelfth of July in the Morning ... (Or the Man Who Mistook His Sash for a Hat)," Folk Music Fournal 8, no. 1 (2001): 67-89.

${ }^{44}$ Sam Hanna Bell, Erin's Orange Lily and Summer Loanen (Belfast: Blackstaff Press, 1996), 12.

${ }^{45}$ Ibid.

${ }^{46}$ It should be noted that there have since been much more overtly anti-Catholic songs introduced into the canon, the most notorious being "The Famine Song," which depicts Catholics as rapists, pedophiles, and Nazi sympathizers. For a detailed deconstruction of this particular piece, see McKerrell, "Hearing Sectarianism," 1-12.

${ }^{47}$ Radford adopts a similar stance when discussing the interpretation of "Aughalee Heroes." She describes the practice of "overlapping layers of loyalism" as providing "a synchronic and diachronic view of particular loyalist perspectives on historical awareness and values." Radford, "Red, White, Blue and Orange," 81.

${ }^{48}$ Thornlie Boys, "Orange Cat/Dolly's Brae," Crossing The Boyne, 2009, compact disc.

${ }^{49}$ Richard Taruskin, The Danger of Music and Other Anti-Utopian Essays (London: University of California Press, 2010 ), 22.
} 
where the majority of the country's Catholics reside, there were approximately two hundred and fifty. ${ }^{50}$ Audiences at an Orange Walk can vary from tens to thousands; when such parades march through the areas most populated by Scotland's Catholic community, which cannot participate in them and interpret them as offensive, Orange Walks and their most popular and iconic anthem, "The Sash," assume a provocative nature. Indeed, never has the old adage "it's not what you say-it's how you say it" seemed more apt.

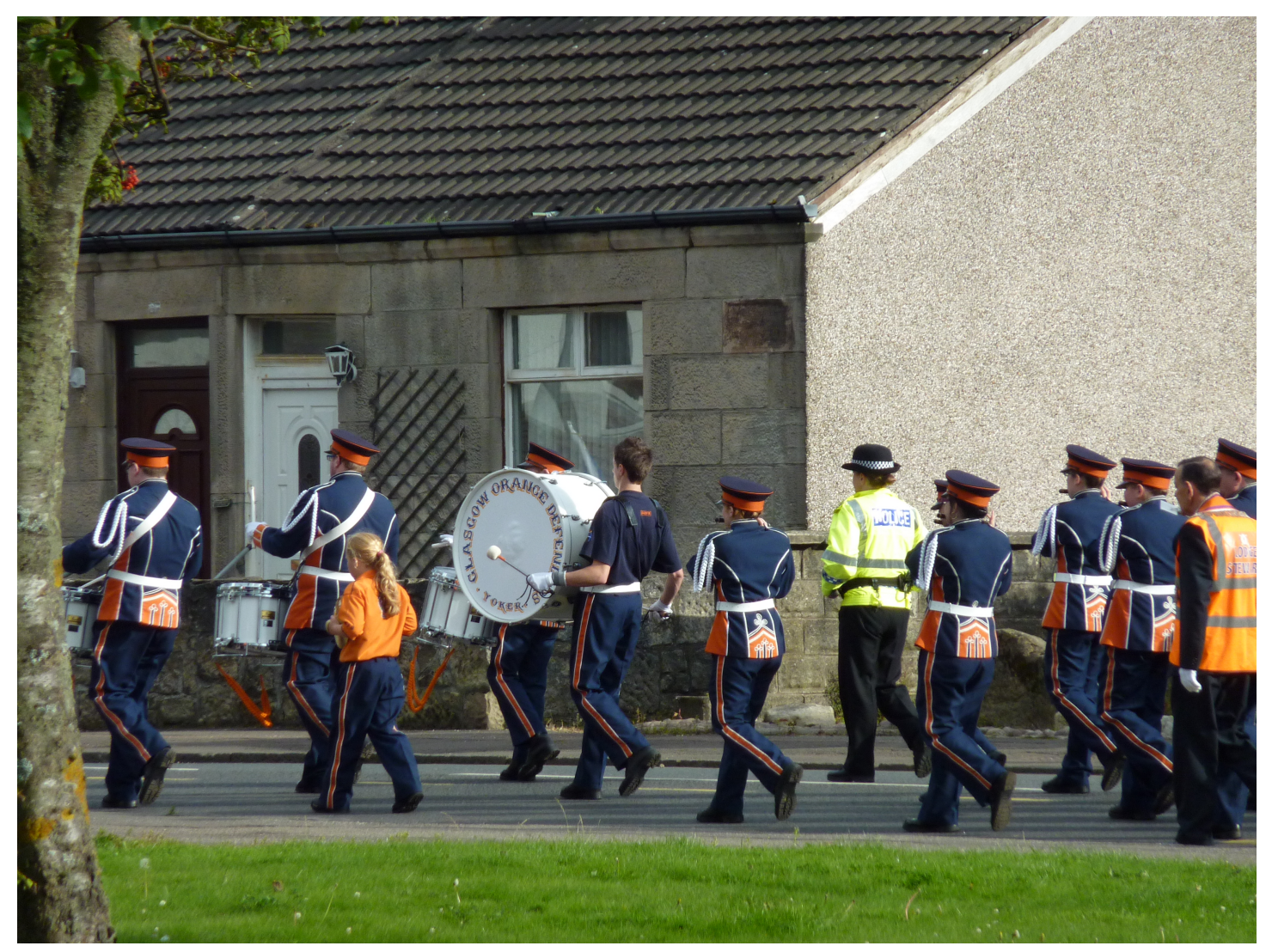

Image 4: An Orange Walk passes through a housing estate in Blantyre. Photograph by Kay Goodall, used with permission.

\section{Music as a Weapon}

In their work on music and violence Bruce Johnson and Martin Cloonan set out the conditions under which music is used as torture:

The idea that one no longer has ownership of one's own sounds is a profound and painful violation. . . . a violation of the victims' identity as human beings, and at the same time an assertion of the material and cultural superiority of the aggressor. . . Being unable to escape the sounds of an economically and culturally hegemonic superpower further diminishes the victim. ${ }^{51}$

Yet this lack of control is similar to that experienced by Catholics in Scotland, or Northern Ireland, when

\footnotetext{
${ }^{50}$ Marshall, The Billy Boys, 150-151.

${ }^{51}$ Bruce Johnson and Martin Cloonan, Dark Side of the Tune: Popular Music and Violence, (Aldershot: Ashgate Publishing Limited, 2008), 158.
} 
confronted by an Orange Walk parading in a public space, supported by the state. Martin Stokes raises this issue in his description of Orange Walks:

The marches are aggressive occasions. It is impossible to disentangle the musical aspect of the parades from the militarism of the banners, and scarcely concealed displays of machismo and supremacism on the part of the marching musicians. ... The lambeg drums are as objects vital symbols of the pride and integrity of Protestant communities, but at the same time, as extremely loud musical instruments, they constitute an assault on the ears. No alternative thought is possible. The drums demand that people either march in time with them, or go away. ${ }^{52}$

Just as it is "impossible to disentangle the musical aspect of the parade from the militarism of the banners," so too is it difficult to differentiate between the "audience" and "participants" in the parade. Although it is relatively easy to identify those playing instruments, or carrying banners as "active participants," beyond this, it becomes difficult to determine an individual's level of participation.

While many of those participating merely walk or follow the parade, they become active participants by the ceremonial clothing they wear: a dark suit and an orange sash. Many of those who go along to watch the parade, as "supporters," choose to wear Glasgow Rangers football shirts: a signifier of their Protestant, Scottish/British, Unionist/Loyalist identity and accompanying ideology. Given that many of these individuals walk alongside the parades, sometimes for several miles, it is debatable as to whether or not they play some part in the performance of an Orange Walk. More interesting still is the role the police play in these events. While a small minority stand at predetermined points of intersection, allowing traffic to pass in the gaps between bands, the majority walk alongside the parade, accompanying them to their final destination. Yet since the police walk in-step with the marchers, the outside observer could be forgiven for thinking that the "police parade" forms part of the Orange parade. Lastly, those on the periphery-both Catholics and disaffected Protestants, caught in the commotion of the event as they try to go about their business-participate in the parade through embodying the Other featured in the lines of such songs as "The Sash," "Boyne Water," and "Derry's Walls." In short, the parade becomes an event through which everyone is a performer, "embraced by a single but fluid continuum of experience."

Drawing on the work of Svanibor Pettan, ${ }^{54}$ Johnson and Cloonan consider the three main uses of music during conflict as "encouragement to participants; provoking and humiliating the enemy; and calls for the involvement of those not directly involved." ${ }^{55}$ It is clear that during an Orange Walk, music is used to encourage the participants. On a practical level music facilitates marching further, breaking the monotony of the march, while simultaneously setting a tempo: this satisfies the first of Johnson and Cloonan's three criteria. The music of an Orange Walk also fulfills the third in that it calls for the involvement of those not directly involved. Drawing on the work of Deleuze and Guattari, Steve Goodman argues that music can be deployed tactically, where its objective is "that of intensification, to the heightening of collective sensation, an attractive, almost magnetic, or vortical force, a force that sucks

\footnotetext{
${ }^{52}$ Martin Stokes, "Introduction" in Ethnicity, Identity and Music: The Musical Construction of Place (Oxford: Berg, 1997$), 9$.

${ }^{53}$ This quote refers to the reception of Bach's Passions by Lutheran audiences, yet the concept of "audience as participant" elucidates parallels within the present discussion of the Orange Walk. For a more detailed analysis, in its original context, see John Butt, Bach's Dialogues with Modernity Perspectives on the Passions (Cambridge: Cambridge University Press, 2010), 235.

${ }^{54}$ Svanibor Pettan, "Music, Politics, and War in Croatia in the 1990s: An Introduction," in Music, Politics and War: Views from Croatia (Zagreb: Institute of Ethnology and Folklore Research, 1998), 13.

${ }^{55}$ Johnson and Cloonan, Dark Side of the Tune, 149.
} 
bodies in toward its source." ${ }^{56} \mathrm{He}$ continues that such force can generate "intensification and collective individuation (to render the crowd as a body in its own right). In this instance, the aim of mobilizing bodies extensively is accompanied and perhaps overridden by the primary objective of the intensive mobilization of affect." ${ }^{57}$ Orange Walks deploy music in a deliberate tactical fashion so as to intensify the collective sensation of both those participating directly in the parade and the recipient audience who are attracted towards the music and feel a "collective individuation" through its calculated use. From their inception, Orange Walks in Scotland were accompanied by violence, ${ }^{58}$ as Catholics perceived such parades as assertive, exclusivist, and colonialist, with an anti-Catholic or anti-Irish ideology. Despite attempts to rebrand Orange Walks, Catholics in Scotland continue to find them offensive and, as such, deploy strategies to avoid them. ${ }^{59}$ A recent report from the Conforti Institute, commissioned by the Scottish Government, interviewed 553 Catholics across central Scotland and found that most identify Orange Walks as the principal manifestation of sectarianism in Scotland. ${ }^{60}$ This strongly suggests that Orange Walks conform to the second of Johnson and Cloonan's "uses of music in conflict": to provoke and humiliate the enemy.

\section{The Billy Boys}

Anti-Catholicism in Scotland was rarely based solely on religious difference, and with the mass Irish immigration of the nineteenth century "Irish" and "Catholic" were conflated into one category whereby an attack on one was often an attack on the other. Today, one of the most visible manifestations of antiCatholicism, and anti-Irish racism, is that which accompanies the rivalry between Scotland's two biggest football teams, Glasgow's Celtic and Rangers, with football-related incidents accounting for the highest number of sectarianism-related arrests. ${ }^{61}$ Many of the teams' supporters use songs, some of which are considered racist and sectarian, to antagonize the other side. ${ }^{62}$ One of the most popular and rousing of such songs, sung by Rangers supporters, is "To Be a Billy Boy," also known as "Hullo, Hullo," sung to the tune of Henry Clay Work’s "Marching Through Georgia."

\footnotetext{
${ }^{56}$ Steve Goodman, Sonic Warfare: Sound, Affect, and the Ecology of Fear (London: MIT Press, 2010 ), 11.

${ }^{57}$ Ibid.

${ }^{58}$ McFarland, Protestants First, 51.

${ }^{59}$ Elinor Kelly, "Challenging Sectarianism in Scotland: The Prism of Racism," Scottish Affairs, no.42 (Winter 2003): 32-56, 46.

${ }^{60}$ Conforti Institute, “Anti-Sectarianism Project Report,” April 2014, 9.

${ }^{61}$ See Amy Goulding and Ben Cavanagh, "Religiously Aggravated Offending in Scotland 2012-2013," (Scottish Government Social Research: Justice Analytical Services, 2013), 4.

${ }^{62}$ While anti-Irish and anti-Catholic songs are classed as "racist" and "sectarian," the songs sung by some Celtic supporters are more contentious, often being dubbed "politically sectarian." See John D. C. Gow, "Political Sectarianism Is Still Sectarianism!," The Rangers Standard, 2013, accessed 11 August 2013, http://www.therangersstandard.co.uk/index.php/articles/rfc-politics/239-political-sectarianism-is-still-sectarianism. The Scottish Government's 2012 "Offensive Behaviour at Football and Threatening Communications Act” saw some Celtic fans charged for singing "politically sectarian songs"; however, given porous definitions on what constitutes "political sectarianism," coupled with difficulties in obtaining court convictions, such a category has proven problematic. See Stuart Waiton, Snobs' Law: Criminalising Football Fans in an Age of Intolerance. (Dundee: Take A Liberty, 2012).
} 


\section{Verses and Chorus of "To Be A Billy Boy"}

The song we sang in days of yore is still our song today,

And Orangemen still proudly march as the flutes and drums do play,

For on that day in each July, it will always give us joy,

To wear The Sash our fathers wore and be a Billy Boy,

For we are the Billy Boys.

Chorus: Hullo, Hullo, we are the Billy Boys,

Hullo, Hullo, you'll know us by our noise,

We're up to our knees in Fenian blood, surrender or you'll die, ${ }^{63}$

For we are the Bridgeton Billy Boys.

Now Tony Blair that noise you hear is Ulster saying "No!"

And the sons of William they will stand to fight the Fenian foe,

We'll walk the streets each twelfth July "No Surrender" is our cry!

And we'll wear The Sash our fathers wore and be a Billy Boy,

For we are the Billy Boys.

Chorus $^{64}$

The "Bridgeton Billy Boys" was a violent, Protestant, and proto-fascist street gang, based in the East End of Glasgow, that violently opposed Irish-Catholic immigration. Named after King William-"King Billy"-it was led by Billy Fullerton and was active during the 1920s and 1930s. The Billy Boys was the largest and most powerful gang in Glasgow and "periodically intervened in local disputes in other districts." ${ }^{65}$ At its peak, the gang comprised some eight hundred members and fought with Catholic street gangs_such as the "Norman Conks"-over control of Glasgow's East End. ${ }^{66}$ In addition to orchestrating inflammatory Orange Walks through the city's Catholic areas, the Billy Boys were also employed by Tory politicians to break-up Socialist, Trade Unionist, and Labour Party meetings; the gang's leader was awarded a medal for strikebreaking in the 1926 General Strike. ${ }^{67}$ That Glasgow's Irish Catholic community "proved more consistently loyal to the parliamentary left than possibly any other element of the Scottish population" could only have increased the zeal with which Fullerton carried out his duties. ${ }^{68}$

\footnotetext{
${ }^{63}$ In its original context the term "Fenian" refers to a group of Irish revolutionaries who fought to end British rule and establish a Republic of Ireland from the mid-nineteenth to the early twentieth century. However, in modern parlance, it is used as a derogatory, slang term to denote a Catholic.

${ }^{64}$ The lyrics of "To Be A Billy Boy" were transcribed from The Billyboy Singers and Friends' 1999 album Forever Loyal. The album was released following Tony Blair's brokering of Northern Ireland's Good Friday Agreement, in 1998, and illustrates loyalist resentment over the concessions made to Sinn Féin and the Provisional IRA. While it is uncommon to hear such verses today, performers focusing on the more rousing—and sectarian—chorus, "To Be A Billy Boy" functions in a similar manner to that of "The Famine Song," wherein "the chorus carries the implied meaning of the whole song as a musical synecdoche in abbreviated form." See McKerrell, "Hearing Sectarianism," 4.

${ }^{65}$ Davies, City of Gangs, 73.

${ }^{66}$ Davies, "They Sing That Song," 53-54.

${ }^{67}$ Glasgow Digital Library, "Resistance to fascism," accessed 26 August 2014, http://gdl.cdlr.strath.ac.uk/redclyde/redclyeve23.htm.

${ }^{68}$ Tom Gallagher, Glasgow The Uneasy Peace: Religious Tension in Modern Scotland, 1819-1914 (Manchester: Manchester University Press, 1987), 182. For more on the influence of Glasgow's Irish Catholic community on the city's socialist politics, see J. McCaffrey, "Irish Issues in the Nineteenth and Twentieth Century," in Irish Immigrants and Society, ed. T. Devine (Edinburgh: John Donald, 1991); J.J. Smyth, Labour in Glasgow, 1896-1936: Socialism, Suffrage, Sectarianism (East Linton, East Lothian: Tuckwell Press, 2000); Martin J. Mitchell, New Perspectives on the Irish in Scotland (Edinburgh: John Donald, 2008).

It is important to state that Billy Fullerton's actions against the Labour Party were not representative of most Orangemen. The rise of trade union power and the establishment of the Labour Party saw many Orangemen change their political allegiance and there was a "growing realisation that their economic and social advancement in society depended more on the political left than it did on the political right.” See Marshall, The Billy Boys, 133.
} 
The use of the offensive and highly emotive phrase "we're up to our knees in Fenian blood" is one of the starkest signifiers of anti-Irishness and anti-Catholicism's enduring place in Scottish society. Although most commonly associated with Rangers Football Club, a team which refused to sign Catholic players from the 1920s to the 1980s, ${ }^{69}$ "To Be a Billy Boy" presents itself as being part of the Orange tradition through the song's support of Twelfth July parades, the wearing of a sash and its support for Ulster loyalists. While the Orange Order is quick to state its opposition to the singing of such overtly sectarian songs and disassociate itself from "To Be a Billy Boy," it is frequently played during Orange Walks. Although bands that play at Orange Walks are paid, and need not be members of the organization, one cannot ignore that there is a connection between this song and the Orange Order. While they would perhaps wish to ignore it, this example highlights a disconnect between the hierarchy of the Orange Order, the rank-and-file, and a section of Scottish society that perceives itself as belonging to this Orange grouping. This disconnect has troubled the Order since its inception and there has always been an uneasy relationship between those attracted to the fraternal nature of the Order and those drawn towards the religious element of the organization. Yet the two groups have enjoyed a symbiotic relationship. McFarland refers to the "rough/respectable" distinction whereby the "rough" contingent only turn out to support the parades, while the "respectable" body are much more involved in the theological aspect of the Order, busying themselves with official lodge business. ${ }^{70}$ In Scotland the "respectable" element of the Order conceded the battle over temperance during the 1960s by sanctioning the licensing of Orange premises $;^{71}$ the "rough" element accepted the Order's denouncement of loyalist paramilitaries in Northern Ireland. ${ }^{72}$

While conducting research for this project I was struck by the number of people who thought "The Sash" featured the line "we're up to our knees in Fenian blood." This was particularly prevalent among older members of my local Catholic church, yet it also featured in discussions with middle-class Protestants. This common mistake is likely facilitated through the close relationship between a vocal minority who support Rangers Football Club, sing sectarian songs, and go along to support the Orange Walk. While many Rangers supporters, members of the Orange Order, and spectators of Orange Walks do not sing sectarian songs, there is an interconnectedness between the three which, when combined, encapsulates the caricature of anti-Catholicism in Scotland. ${ }^{73}$ The close association between the sectarian songs of Rangers Football Club, Orangeism, and "The Sash" blurs the boundaries of ethno-religious offence and augments the inflammatory nature of Orange Walks. The misappropriation of "up to our

\footnotetext{
${ }^{69}$ Bruce, Sectarianism in Scotland, 128-129.

${ }^{70} \mathrm{McF}$ arland, Protestants First, 140-143.

${ }^{71}$ Marshall, The Billy Boys, 168.

${ }^{72}$ The Scottish Orange Lodge Grand Secretary, David Bryce, publicly denounced paramilitary violence in 1979 saying, " $[\mathrm{t}]$ here is no place in our organisation for people like those convicted or for anyone involved in paramilitary organisations." This was shown when the Grand Lodge of Scotland suspended the officers of an Edinburgh lodge that refused to expel two members fundraising for loyalist paramilitaries in Northern Ireland. A more musical example was that of the Cowdenbeath flute band ordered off of a parade in Broxburn, West Lothian, for wearing UVF uniforms and carrying UVF banners. For more see Bruce et al., Sectarianism in Scotland, 126-127. While there were instances of Scottish Orangemen convicted for their involvement with loyalist paramilitaries, such instances were rare and, as above, condemned by the Orange Order. For more on the connection between Scottish Orangemen and loyalist paramilitaries, see R. Michael Booker, "Orange Alba: The Civil Religion of Loyalism in the Southwestern Lowlands of Scotland since 1798" (Ph.D. dissertation, University of TennesseeKnoxville, 2010), 101-102.

${ }^{73}$ In his examination of this group within a larger historical context, Booker expands this to include loyalist street gangs, paramilitaries, and loyalist flute bands which, along with the Orange Order and Rangers Football club, he classifies as a "loyalist civil religion" where each of these groups forms part of a "multidimensional and interactive civil religious movement." Booker, "Orange Alba," iii.
} 
knees in Fenian blood," as lyrics pertaining to "The Sash," negates previous efforts to sanitize the Orange Walk by replacing songs such as "Dolly's Brae" with "The Sash." Bill Rolston refers to this process as "lyrical drift," whereby the meaning of a song is removed from its original context "and reinterpreted by an audience in a different political context."

Just as many sectarian songs are often contrafacta, it could be argued that "The Sash" has assumed the meaning of a sectarian song, despite its lack of overtly sectarian lyrics. ${ }^{75}$ Indeed, one only has to look at the way it is used by some Rangers supporters, particularly when playing against archrivals Celtic, to appreciate that it is used to taunt and antagonize the opposition. In a BBC documentary on the links between football and sectarianism, a young inmate at Polmont, the largest young offenders institution in Scotland, explained how hearing "The Sash" made him feel. The young man, identified in the film as "Brian Celtic Supporter," said:

I hate it, I hate it. It gets us really mad. That's how people get hurt. That's how people end up getting murdered. That's a cause of it. You come out of the grounds, the hate's building up in you, you're getting really, really mad and it gets to the stage where you're saying to yourself 'the first Rangers fan I see I'm just gonnae run up and heeder [head-butt] him'. ${ }^{76}$

In another documentary, made during the mid-1990s, a man who described himself as "Catholic" and "a Celtic supporter" said of Orange Walks: "They're not marching for liberty and they're not marching for anything else. What they're marching for is to aggravate the Catholics." "W7 While it is true that "The Sash" has been appropriated by other groups seeking to utilize the legitimacy of the Order, there are bands that continue to play sectarian songs while participating in Orange Walks under the auspices of the Orange Order. Whether these bands choose to play sectarian songs for their own enjoyment or whether they are merely "playing to the crowd" is difficult to determine: it is a microcosm of the tensions inherent within the Orange Order.

Irish Catholics who immigrated to Scotland have retained some semblance of an alternative identity through social and cultural institutions, such as separate Catholic schools, Celtic Football Club, and the Ancient Order of Hibernians, yet they have largely assimilated into Scottish society. ${ }^{78}$ Although some Scottish Catholics of Irish descent feel uncomfortable referring to themselves as "British," perhaps on account of Britain's role in the Troubles, or the Union Flag's long association with Protestantism, few would object to being called Scottish. ${ }^{79}$ Yet in spite of all of this, many Scottish Catholics continue to feel antagonized by Orange Walks, interpreting them as a "test of their Scottishness" and perceive them as being directed at the Catholic community on account of its Otherness. In their 2003 report Sectarianism in

\footnotetext{
${ }^{74}$ Bill Rolston, “This is not a Rebel Song': The Irish Conflict and Popular Music,” Race E Class 42, no. 3 (2001): $49-67$.

${ }^{75}$ While "The Sash" does not contain any overtly sectarian sentiment within its lyrics, there have been instances where "fuck the Pope" has been shouted as an "add-in" at the end of the song. In the video included above this can be heard—faintly-at the end of the crowd's rendition of the song.

${ }^{76}$ Panorama, Scotland's Secret Shame, BBC1, broadcast 27 February 2005, television.

77 Witness, Football, Faith and Flutes, Channel 4, broadcast 12 November 1995, television.

${ }^{78}$ It should be noted that some Catholics of Irish descent identify as "Irish." While such self-identification is not controversial in other parts of the world, such as the United States, in Scotland it has often been met with fierce criticism. One high-profile example was that of the former Celtic footballer Aidan McGeady, who chose to play for the Republic of Ireland over the Scottish national team. McGeady, who was born and raised in Scotland, had Irish paternal grandparents so qualified to play for the Republic of Ireland. His decision was criticized by the press, and in the infamous anti-Irish, antiCatholic "Famine Song" McGeady is referred to as "that wee traitor from Castlemilk [who] turned his back on his own." For more on the "The Famine Song," see McKerrell "Hearing Sectarianism," 1-12.

${ }^{79}$ Rosie, The Sectarian Myth in Scotland, 16.
} 
Glasgow, the NFO found that, overall, 53 percent of respondents supported a ban on Orange Walks. ${ }^{80}$ Yet of the 53 percent in favor of a ban on Orange Walks, two thirds were Catholic and only one third were Protestant. ${ }^{81}$ Thus, while the majority of Catholics supported a ban on Orange Walks, the majority of Protestants opposed such a ban. More interestingly, while 56 percent of respondents believed that Catholic and Irish/Republican marches should be banned, the majority of Catholics favored such a ban while the majority of Protestants opposed it. ${ }^{82}$ That the majority of Catholics favor a ban on all parades, while Protestants oppose such a blanket ban is, perhaps, unsurprising. Over half of all Scotland's annual public processions are organized by the Orange Order; in Glasgow Orange Walks account for 85 percent of the city's parades. ${ }^{83}$ Thus such figures suggest a sensitivity on the part of Catholics that is not matched by those who identify as Protestant, perhaps due to the relatively small size of Scotland's Catholic community and the disproportionate number of parades they see as being directed against them.

\section{Conclusion}

The Modernist composer and musical theorist Hanns Eisler believed that music could become a new method of discourse and wrote that it "should not turn a 'deaf ear' to the conflicts of the times." ${ }^{\prime 4}$ Eisler's writings focused on educating the proletariat through music, and while primarily concerned with the emancipation of the working class, his message that music could be used to educate the masses and challenge the fixed mentality of the minority could equally be applied to the challenging of bigoted attitudes through music. Fifteen years have passed since James MacMillan “opened Pandora's box," and this discourse has now bled into popular music. Scottish bands such as Ballboy and Mogwai have written songs entitled "The Sash My Father Wore" and "Scotland's Shame," respectively, demonstrating pop culture's recognition of Scotland's sectarian problems. Ballboy's "The Sash My Father Wore" paints the sad picture of a stereotypical working-class Scottish bigot and features the lines:

You've got Billy tattooed on your neck,

And a Union Jack above your bed,

You've got nothing intelligent to say,

And no-one's listening, to you, anyway.

'Cause you're a big, fat, bigoted arsehole $(\mathrm{x} 4)^{85}$

The song focuses on deriding sectarianism's uneducated, underprivileged foot soldiers and sidesteps the more serious issue of challenging the deeply ingrained belief that it is acceptable for an ethno-religious majority to bully a minority, unopposed, in a public space. ${ }^{86}$ But it is a start. Ballboy's venture into an area many would rather not confront marks a change in attitudes towards sectarianism in Scotland and displays a readiness to engage with the problem directly.

More recently, The Wakes, a folk-rock band from Glasgow, engaged in the discourse around Scotland's sectarianism on its in 2009 album No Irish Need Apply. "From the Gutter to the White House"

\footnotetext{
${ }^{80} \mathrm{NFO}$, “Sectarianism in Glasgow," 44.

${ }^{81}$ Ibid.

${ }^{82}$ Ibid.

${ }^{83}$ Orr, Review of Marches and Parades in Scotland, 69.

${ }^{84}$ Lydia Goehr, "Political Music and the Politics of Music," The fournal of Aesthetics and Art Criticism 52, no. 1 (1994): 99.

${ }^{85}$ Ballboy, "The Sash My Father Wore," The Sash My Father Wore and Other Stories, SL Records, 2003, compact disc.

${ }^{86}$ While this may not be the intention of those participating in the parade, it is the perception of many Catholics interpreting it who see the Orange Walk as "an expression of hatred towards the Catholic community." Conforti Institute, "AntiSectarianism Project Report," 9.
} 
tells of the Irish diaspora's struggle for acceptance around the world and features discussion of the difficulty around expressing an Irish identity in Scotland:

In the west of Scotland, though we preserve identity,

There's not been full acceptance into Scots society,

'Cause if you sing the [Irish] national anthem, you'll be accused of bigotry,

It's nothing but the same old story, for the twenty-first century. ${ }^{87}$

While such accusations may seem farfetched, they are ongoing. In 2002, an award-winning columnist for The Herald wrote of Celtic supporters, "[t]hey flap the Irish tricolour and sing sad Irish songs and roar of the Irish struggle. There's a country called Ireland, for goodness sake; why don't they go and live there?" 88

Continuing their theme of music, football, and sectarianism in Scotland, the first single from The Wakes' 2013 album, The Red and the Green, was entitled "Colours," and outlines Glasgow's sectarianism and its interconnectedness with football: Celtic and Rangers being the green and the blue.

Video 2: "Colours," the Wakes.

View at: http://dx.doi.org/10.3998/mp.9460447.0009.102

\section{Verses and Chorus of "Colours"}

Chorus: The colours are green, the colours are blue,

When you're born in this world they give the colours to you,

You don't have a choice.

In a city that's shaped by the scars of the past,

Our colours are taken, nailed to the mast,

To the songs of the tribes.

Some blame it on religion, some call it "The Holy War"

A subdivision to cut a city to the core,

Another derby day, another casualty,

And all the papers say "it's just another Saturday."

Chorus

One hundred years of hate and violence,

Has brought you home to deathly silence,

Your son's not coming home.

History revisited by drunk teenage boys,

Too young to remember it, but old enough to die,

And the papers say "wrong place, wrong time."

This is our city and these are our colours (x8)

Bang the drum, bang the drum, you're up to your knees in hate

Who taught you to hate? (x2)

In a city that's shaped by the scars of the past,

Our colours are taken, nailed to the mast,

To the songs of the tribes.

The colours are green, the colours are blue,

When you're born in this world they give the colours to you,

You don't have a choice. ${ }^{89}$

\footnotetext{
${ }^{87}$ The Wakes, "From the Gutter to the White House," No Irish Need Apply, Big Hooley Records, 2009 , mp3.

${ }^{88}$ John MacLeod, "Negative Labels that are the lot of the Protestant," The Herald, 18 February 2002.

${ }^{89}$ The Wakes, "Colours," The Red and the Green, Big Hooley Records, 2013, mp3.
} 
The Wakes' reference to the "songs of the tribes" links the music to Glasgow's sectarian problems; the more explicit "bang the drum, bang the drum, you're up to your knees in hate" reinforces the connection between the drums of the Orange Walk and the aforementioned "To Be a Billy Boy."

In a similar instance of popular culture being used to openly challenge sectarian attitudes in Scotland, there have been several theatrical productions aimed at tackling the issue. Des Dillon's Singin' I'm No a Billy He's a Tim, charts the relationship of two working-class men who are forced to share a police cell on the day of a Celtic and Rangers, "Old Firm" match. Both men are bigots, each from the opposing side, and the play charts how Scotland's sectarianism has molded their attitudes into direct opposition. ${ }^{90}$ Singin' I'm No a Billy He's a Tim was hailed as a success, receiving a five-star review from the Irish Post, and has had five national sell-out tours in Scotland and Northern Ireland. ${ }^{91}$ Perhaps this further signifies a changing of public attitudes towards sectarianism and represents a willingness to re-engage in the national debate, which began with James MacMillan's lecture, but has yet to be resolved.

In the approach to a referendum on whether Scotland should leave the United Kingdom and become an independent country-on September 18, 2014-the Orange Order staged a pro-Union parade in the country's capital, comprising over ten thousand band members and marchers-the biggest referendum gathering, on either side, of 2014. Yet those political parties opposing Scottish independence, campaigning collectively as Better Together, publicly distanced themselves from the Order, with one Labour M.P. referring to them as an "unsavory" organization. ${ }^{92}$ Fearful of alienating Catholic voters, Better Together called on the Orange Order to abandon its rally, yet the parade went ahead and Scotland voted to maintain its Union with England, Wales, and Northern Ireland. While the country as a whole voted against independence, Glasgow—Scotland's biggest city—voted in favor of it. In response, British loyalists staged a victory rally in the city's George Square, which quickly turned violent and saw said loyalists clashing with those from the independence campaign while draped in Union Flags and chanting British loyalist and anti-Irish/anti-Catholic songs. While it would be erroneous to conflate Catholics en mass with the independence campaign, support for Scottish independence was higher among Catholics than any other group, and the Orange Order seized upon connections between the two. ${ }^{93}$

Following the result, impromptu Orange Walks were staged in my hometown of Motherwell, and loyalist anthems such as "The Sash" and "Derry's Walls," the latter containing the lines "the cry was no surrender," were performed with gusto. The flurry of phone calls from Catholic friends and family conveyed outrage at such flagrant displays of triumphalism-Motherwell's voting for independence and housing a large Catholic community making such displays particularly problematic. Yet, as outlined in the Conforti Institute's report, ${ }^{94}$ such interpretation of Orange Walks is in keeping with Catholic

\footnotetext{
${ }^{90}$ Other recent examples include Hector MacMillan's The Sash, Jenifer Adam's Kiss Cuddle, Torture, and Jen McGregor's Creepie Stool.

91 “Singin' I'm No A Billy He's A Tim," The Pavilion Theatre Glasgow, accessed 2 September 2014. http://www.paviliontheatre.co.uk/shows/singin-im-no-a-billy-hes-a-tim-2/.

${ }^{92}$ Neil Mackay et al., "Orange Order vows march to save Union will go ahead after violence mars Glasgow walk," The Herald, 6 July 2014, http://www.heraldscotland.com/news/home-news/orange-order-vows-march-to-save-union-will-go-ahead-afterviolence-mars-glasgow-walk.24682752.

${ }^{93}$ Gerry Braiden, "Catholics are most pro-Yes religious group, claims academic," The Herald, 17 March 2014, http://www.heraldscotland.com/news/home-news/catholics-are-most-pro-yes-religious-group-in-scotland.23704996.

${ }^{94}$ Conforti Institute, "Anti-Sectarianism Project Report," 9.
} 
interpretation across west-central Scotland. Loyalist bands' calculated use of such songs suggests an awareness of their political power and a desire to use it against those outside their ranks and opposed to their ideology, "offering encouragement to participants; provoking and humiliating the enemy; and calling for the involvement of those not directly involved." W5 With Scotland's place in the Union secure, such use of music during conflict seems set to continue for some time.

\section{Bibliography}

Adamson, Ian. "The Ulster-Scottish Connection." In Scotland \& Ulster, edited by Ian S. Wood, 1-21. Edinburgh, Mercat Press, 1994.

Bell, Sam Hanna. Erin's Orange Lily and Summer Loanen. Belfast: The Blackstaff Press Limited, 1996.

Booker, R. Michael. "Orange Alba: The Civil Religion of Loyalism in the Southwestern Lowlands of Scotland since 1798.” Ph.D. dissertation, University of Tennessee-Knoxville, 2010.

Bradley, Joseph M. Ethnic and Religious Identity in Modern Scotland: Culture, Politics and Football. Aldershot: Avebury Ashgate Publishing Limited, 1995.

Bruce, Steve. No Pope of Rome: Anti-Catholicism in Modern Scotland. Edinburgh: Mainstream Publishing Company, 1985.

Bruce, Steve, Tony Glendinning, Iain Paterson, and Michael Rosie. Sectarianism in Scotland. Edinburgh: Edinburgh University Press, 2004.

Bryce, David. The Birth of Orangeism: The Battle of the Diamond. Reddrich Press, 2008.

Butt, John. Bach's Dialogue with Modernity: Perspectives on the Passions. Cambridge: Cambridge University Press, 2010. http://dx.doi.org/10.1017/CBO9780511674778.

Davies, Andrew. City of Gangs. London: Hodder \& Stoughton, 2013.

—_. "They Sing That Song': Football and Sectarianism in Glasgow during the 1920s and 1930s." In Bigotry, Football and Scotland, edited by John Flint and John Kelly. Edinburgh: Edinburgh University Press, 2013.

Davis, Graham. The Irish in Britain 1815-1914. Dublin: Hill and MacMillan, 1991.

Devine, T. M. Scotland's Shame? Bigotry and Sectarianism in Modern Scotland. Edinburgh: Mainstream Publishing Company, 2000.

—_. "The End of Disadvantage?" In New Perspectives on the Irish in Scotland, edited by Martin J. Mitchell. Edinburgh: John Donald, 2008.

Edwards, Ruth Dudley. The Faithful Tribe: An Intimate Portrait of the Loyal Institutions. London: HarperCollins, 1999.

Eisler, Hanns. A Rebel In Music. Translated by Marjory Meyer. Berlin: Seven Seas Publishers, 1978.

Evans, Eric J. The Forging of the Modern State: Early Industrial Britain 1783-1870. 3rd ed. Harlow, England: Longman, 2001.

Gallagher, Tom. Glasgow The Uneasy Peace: Religious Tension in Modern Scotland, 1819-1914. Manchester: Manchester University Press, 1987.

Goehr, Lydia. "Political Music and the Politics of Music." The Journal of Aesthetics and Art Criticism 52, no.1 (1994): 99-112. http://dx.doi.org/10.2307/431589.

\footnotetext{
${ }^{95}$ Johnson and Cloonan, Dark Side of the Tune, 149.
} 
Goodman, Steve. Sonic Warfare: Sound, Affect and the Ecology of Fear. London, England: MIT Press, 2010.

Goulding, Amy, and Ben Cavanagh. "Charges reported under the Offensive Behaviour at Football and Threatening Communications (Scotland) Act (2012) in 2012-13." Scottish Government Social Research, Justice Analytical Services, 2013.

Handley, James Edmund. The Irish in Scotland: 1798-1845. 2nd ed. Cork: Cork University Press, 1945.

Hobsbawm, Eric, and Terrence Ranger. The Invention of Tradition. Cambridge, England: Cambridge University Press, 1983.

Jarman, Neil. Material Conflicts: Parades and Visual Displays in Northern Ireland. Oxford: Berg, 1997.

Johnson, Bruce, and Martin Cloonin. Dark Side of the Tune: Popular Music and Violence. Aldershot: Ashgate Publishing Limited, 2008.

Kelly, Elinor. "Challenging Sectarianism in Scotland: The Prism of Racism." Scottish Affairs, no.42 (Winter 2003): 1-25.

Levy, Liz. "An Examination of the Evidence on Sectarianism in Scotland." Scottish Government Social Research, Justice Analytical Services, 2013.

MacMillan, James. "Scotland's Shame." In Scotland's Shame? Bigotry and Sectarianism in Modern Scotland, ed. T. M. Devine, 13-24. Edinburgh: Mainstream Publishing, 2000.

Marshall, William S. 'The Billy Boys:' A Concise History of Orangeism in Scotland. Edinburgh: Mercat Press, 1996.

McCaffrey, J. "Irish Issues in the Nineteenth and Twentieth Century." In Irish Immigrants and Society, edited by T. Devine. Edinburgh: John Donald, 1991.

McFarland, E.W. Protestants First: Orangeism in Nineteenth Century Scotland. Edinburgh: Edinburgh University Press, 1990.

McKerrell, Simon. "Hearing Sectarianism: Understanding Scottish Sectarianism as Song." Critical Discourse Studies (2012): 1-12.

Mitchell, Martin J. New Perspectives on the Irish in Scotland. Edinburgh: John Donald, 2008.

Motherway, Susan. The Globalization of Irish Traditional Song Performance. Aldershot: Ashgate, 2013.

NFO Social Research. Sectarianism in Glasgow - Final Report. Edinburgh, NFO Social Research, January 2003.

Orr, Sir John. Review of Marches and Parades in Scotland. Edinburgh: Scottish Ministers, Scottish Executive, St Andrews House, 2005.

Radford, Katy. "Drum Rolls and Gender Roles in Protestant Marching Bands in Belfast." British Journal of Ethnomusicology 10, no. 2, (2001): 37-59. http://dx.doi.org/10.1080/09681220108567319.

—_. "Red, White, Blue and Orange: An Exploration of Historically Bound Allegiances through Loyalist Song." The World of Music 46, no. 1 (2004): 71-89.

Ramsey, Gordon. Music, Emotion and Identity in Ulster Marching Bands. Bern: Peter Lang, 2011.

Reilly, Patrick. "Kicking With The Left Foot: Being Catholic in Scotland.” In Scotland's Shame? Bigotry and Sectarianism in Modern Scotland, ed. T. M. Devine, 29-39. Edinburgh: Mainstream Publishing, 2000.

Rolston, Bill. “'This is not a Rebel Song:' The Irish Conflict and Popular Music.” Race E Class 42, no. 3 (2001): 49-67. http://dx.doi.org/10.1177/0306396801423003.

Rosie, Michael. The Sectarian Myth in Scotland: Of Bitter Memory and Bigotry. Basingstoke: Palgrave Macmillan, 2004. http://dx.doi.org/10.1057/9780230505131. 
Sewell, Dennis. Catholics: Britain's Largest Minority. London: Viking, 2001.

Scott, George. The R.Cs: A Report on Roman Catholics in Britain Today. London: Hutchinson, 1967.

Smyth, J. J. Labour in Glasgow, 1896-1936: Socialism, Suffrage, Sectarianism. East Linton, East Lothian: Tuckwell Press, 2000.

Stokes, Martin. Ethnicity, Identity, and Music: The Musical Construction of Place. Oxford: Berg, 1997.

Taruskin, Richard. The Danger of Music and Other Anti-Utopian Essays. London: University of California Press, 2010.

Waiton, Stuart. Snobs' Law: Criminalising Football Fans in an Age of Intolerance. Dundee: Take a Liberty Scotland, 2012.

Walker, Graham. "Sectarian Tensions in Scotland: Social and Cultural Dynamics and the Politics of Perception." In Scotland's Shame? Bigotry and Sectarianism in Modern Scotland, ed. T. M. Devine, 125134. Edinburgh: Mainstream Publishing, 2000.

Witherow, Jaqueline. “The 'War on Terrorism' and Protestant Parading Bands in Northern Ireland.” Quest (Queen's University Belfast), no. 1 (2006). http://www.qub.ac.uk/sites/QUEST/. 


\begin{abstract}
This article examines the music used by the Orange Order, in its public parades, more commonly referred to as "Orange Walks." The Orange Order is an exclusively Protestant fraternal organization, which traces its roots to 1690 and the victory of the Protestant Prince William of Orange over the Catholic King James. Yet, as in Northern Ireland, many consider the group to be sectarian and view its public celebrations as a display of ethno-religious triumphalism. This article explores the extra-musical factors associated with Orangeism's most iconic song, "The Sash My Father Wore," how other groups have misappropriated the song, and how this has distorted its meaning and subsequent interpretation.

Recent statistics have shown that Glasgow hosts more Orange parades each year than in Belfast and Derry/Londonderry combined, yet while there have been many anthropological and ethnomusicological studies of Northern Ireland's Orange parades, very little research has focused on similar traditions in Scotland. This article seeks to address that gap in the literature and is intended as a preparatory study, laying the groundwork for further analysis.
\end{abstract}

